\title{
miRNAs and Leukotrienes in Respiratory Syncytial Virus Infection
}

\author{
Zhi Liu ${ }^{1 \dagger}$, Panpan Fan ${ }^{1 \dagger}$, Ming Chen ${ }^{1,2}$, Yueshi $\mathrm{Xu}^{1}$ and Dongchi Zhao ${ }^{1 *}$ \\ ${ }^{1}$ Department of Pediatrics, Children's Digital Health and Data Center, Zhongnan Hospital of Wuhan University, Wuhan, China, \\ ${ }^{2}$ Xiangyang Central Hospital, Affiliated Hospital of Hubei University of Arts and Science, Xiangyang, China
}

MicroRNAs (miRNAs) are small, non-coding RNAs that regulate posttranscription by binding to $3^{\prime}$-untranslated regions of target mRNAs. Recent functional studies have elucidated mechanisms that miRNAs regulate leukotriene synthesis by perturbing arachidonic acid metabolism. Both microarrays and high-throughput sequencing revealed distinct differential expression of miRNAs in children with respiratory syncytial virus (RSV) infection compared with healthy controls. Abnormal miRNA expression may contribute to higher leukotriene levels, which is associated with airway hyperreactivity. Targeting miRNAs may benefit to restore the homeostasis of inflammatory reaction and

OPEN ACCESS

Edited by:

Bülent Taner Karadağ, Marmara University, Turkey

Reviewed by:

Abhijeet Anil Bakre,

University of Georgia, United States Jun Miyata,

National Defense Medical College, Japan

*Correspondence:

Dongchi Zhao

zhao_wh2004@hotmail.com

tThese authors have contributed equally to this work and share first authorship

Specialty section: This article was submitted to Pediatric Infectious Diseases, a section of the journal Frontiers in Pediatrics

Received: 02 September 2020 Accepted: 17 March 2021

Published: 29 April 2021

Citation:

Liu Z, Fan P, Chen M, Xu Y and

Zhao D (2021) miRNAs and Leukotrienes in Respiratory Syncytial

Virus Infection.

Front. Pediatr. 9:602195.

doi: 10.3389/fped.2021.602195 provide new strategies to alleviate airway hyperreactivity induced by RSV. In this article, we provide an overview of the current knowledge about miRNAs modulating leukotrienes through regulation of arachidonic acid metabolism with a special focus on miRNAs aberrantly expressed in children with RSV infection.

Keywords: microRNA, arachidonic acid, leukotriene, respiratory syncytial virus, children

\section{INTRODUCTION}

Respiratory syncytial virus (RSV) is the most common pathogen of acute lower respiratory infection in children and the leading cause of hospitalization in childhood, which results in a great burden on global health-care services $(1,2)$. Due to high morbidity and mortality, RSV infection poses a serious threat to children's health, especially for premature infants, or infants with congenital heart disease or primary immunodeficiency (3-5). RSV is a single-strand negative RNA virus belonging to the Paramyxoviridae family and the Pneumovirus genus. RSV encodes 11 proteins including two non-structural proteins 1 and 2 (NS1 and NS2), structural proteins such as membrane envelope glycoproteins (F and $\mathrm{G}$ ), and matrix proteins $(\mathrm{M})$. These proteins are critical pathogenic factors to induce airway hyperreactivity (AHR), including immune disorder, overexpression of Th2-type cytokines, and inflammatory disequilibrium (6-8). RSV infection in early childhood induces AHR and contributes to the subsequent development of recurrent wheezing $(9,10)$. Increasing leukotriene levels are crucial for the occurrence of AHR after RSV infection and related to recurrent wheezing attacks (11). However, the mechanism of leukotriene upregulation after RSV infection is not clear yet.

MicroRNAs (miRNAs), a type of endogenous non-coding RNAs with a length of 18 to 25 nucleotides, are the most important molecules in the posttranscriptional regulation of gene expression (12). MiRNAs nearly precisely fine-tune the intensity of the cellular signals which are activated by RSV and associated with AHR (13-16). Many miRNAs have been confirmed to be abnormally expressed after RSV infection, some of which negatively regulate AHR, such as miR-24, miR-27, and let-7 family (17-21), others positively, such as miR-140-5p and miR-146b (22, 23). Recently, accumulating evidence demonstrated that miRNAs play an important role in regulating 
the synthesis and balance of lipid inflammatory mediators (24). The regulatory networks of miRNAs on leukotriene synthesis after RSV infection have not been explained in detail. Therefore, here we present an updated review on this issue.

\section{LEUKOTRIENE SYNTHESIS AND RSV INFECTION}

In humans, leukotrienes are produced by leukocytes, bronchial epithelial cells, and fibroblasts. The biosynthetic pathway of leukotrienes is briefly outlined in Figure 1. 5-Lipoxygenase (5LOX) and 5-lipoxygenase-activating protein (FLAP) are critical determinants of leukotriene biosynthesis (25). 5-LOX carries out the first steps in the 5-LOX pathway of leukotriene synthesis. FLAP plays an important role in the coupling of cPLA2 to 5-LOX at the perinuclear membrane. Under the action of 5-LOX and FLAP, leukotriene $\mathrm{A}_{4}\left(\mathrm{LTA}_{4}\right)$ is synthesized from free arachidonic acid $(\mathrm{AA})$ released by phospholipase $\mathrm{A}_{2}\left(\mathrm{PLA}_{2}\right)$ from membrane glycerophospholipids (26). Then, $\mathrm{LTA}_{4}$ is transformed to $\mathrm{LTB}_{4}$ and $\mathrm{LTC}_{4}$ by $\mathrm{LTA}_{4}$ hydrolase $\left(\mathrm{LTA}_{4} \mathrm{H}\right)$ and $\mathrm{LTC}_{4}$ synthase $\left(\mathrm{LTC}_{4} \mathrm{~S}\right)$, respectively. $\mathrm{LTD}_{4}$ and $\mathrm{LTE}_{4}$ are synthesized from $\mathrm{LTC}_{4} \cdot \mathrm{LTC}_{4}, \mathrm{LTD}_{4}$, and $\mathrm{LTE}_{4}$ are collectively called cysteinyl leukotrienes (CysLTs) (27). Released AA can also be oxidized to prostaglandin $\mathrm{H} 2\left(\mathrm{PGH}_{2}\right)$ by cyclooxygenase $(\mathrm{COX})$ or converted to specialized pro-resolving mediators (SPMs) by 12 lipoxygenase (12-LOX)/15-lipoxygenase (15-LOX). Inhibition or enhancement of these metabolic pathways of AA may also take a great effect on the formation or resolving of leukotrienes. Furthermore, all these enzymes mentioned above play essential regulatory roles and do not act alone but form distinct complexes on the nuclear membrane (28).

Over the last decades, different studies have demonstrated the elevations in locally produced $\mathrm{LTC}_{4}$ during RSV infection $(29,30)$, which may persist beyond 1 month after the onset of infection (31). The level of LTC4 was positively correlated with disease severity $(30,32)$. Persistent elevated LTC $_{4}$ levels in nasopharyngeal aspirates (NPAs) were observed in infants who suffered from wheezing compared with the group without symptoms after the acute RSV infection (33). Besides, high levels of $\mathrm{LTB}_{4}$ and CysLTs were detected in the culture supernatant of RSV-infected human bronchial epithelial cells (HBEC) (34, 35). Further studies suggest that RSV induces the expression of 5-LOX in bronchial epithelial cells and thus increases airway inflammation (35). In a RSV-infected mouse model, inhibiting FLAP could reduce inflammation (36). In addition, RSV may regulate leukotriene synthesis by disrupting the COX pathway. The expression levels of COX-2 are upregulated in peritoneal and alveolar macrophages of cotton rats infected with RSV (37).

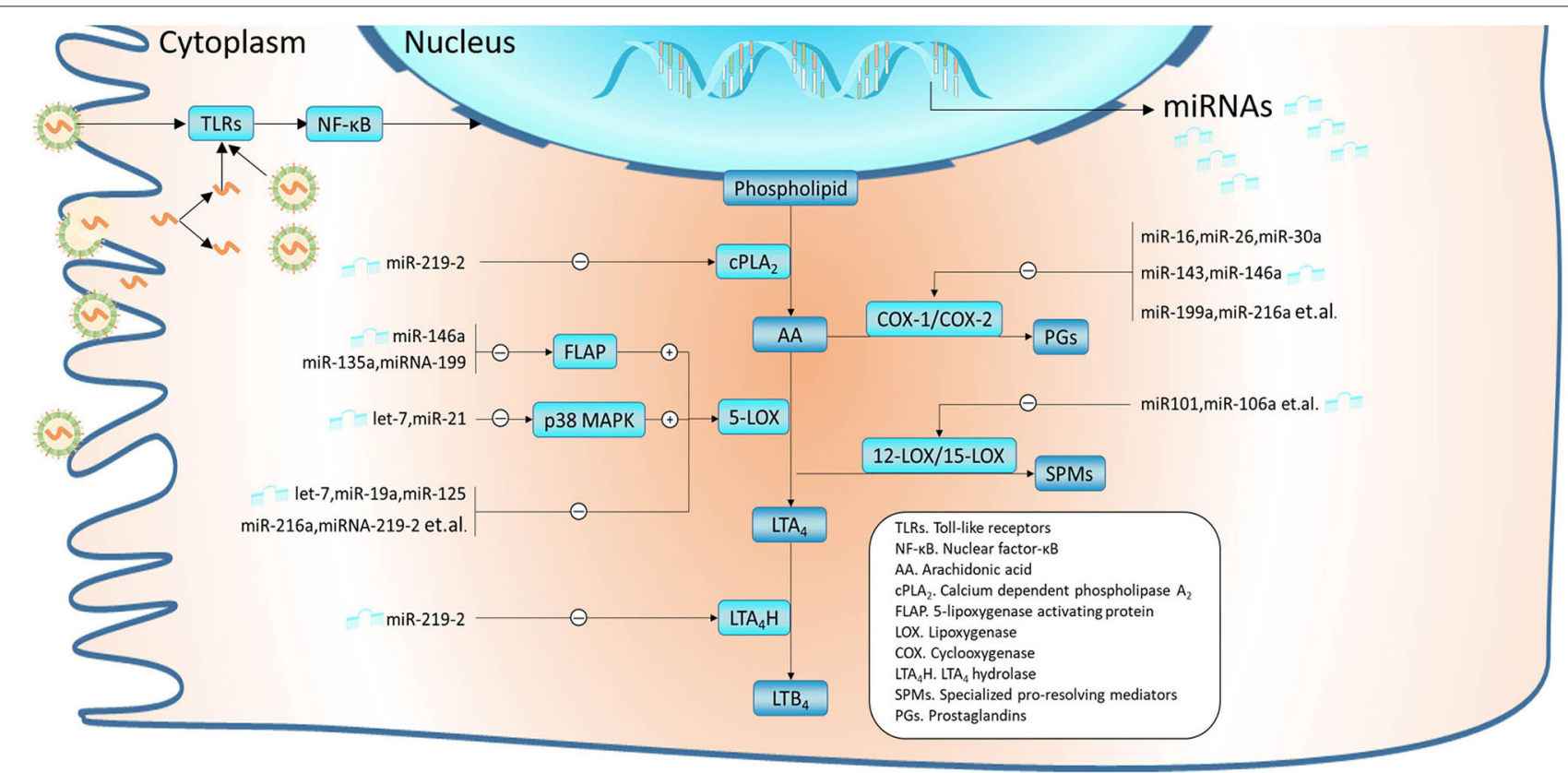

FIGURE 1 | miRNAs were validated to modulate the metabolism of arachidonic acid (AA). In airway epithelial cells, RSVs are recognized by PAMPs such as TLRs, which subsequently activate signal pathways like NF-kB and affect the expression profile of miRNAs. MiRNAs regulate leukotriene synthesis by modulating AA metabolism, which mainly includes the LOX pathway and COX pathway. Thereinto, miR-219-2 can inhibit several enzymes such as cPLA2, 5-LOX, and LTA 4 H. Some miRNAs have been confirmed to inhibit the expression of 5-LOX, such as let-7, miR-19a, and miR-125. In addition, miR-146a, miR-135a, and miR-199 can regulate 5-LOX enzyme activity by downregulating FLAP; let-7 and miR-21 by downregulating p38 MAPK. Interference with these miRNAs may contribute to the consistently overexpressed leukotrienes. MiRNAs such as miR-16, miR-26, miR-30a, miR-143, and miR-146a may lead to the conversion of more AA to leukotriene by inhibiting the COX pathway. Besides, overexpression of miRNAs like miR-101 and miR-106a can suppress 12-LOX/15-LOX, which could disrupt the balance between pro-inflammatory and inflammation-resolving mediators. Among these miRNAs, let-7, miR-16-5p, miR-19a, miR-21, miR-26b, miR-30a-5p, miR-125a, miR-143, and miR-146a have been found abnormal expression in RSV infection. 


\section{miRNAs EXPRESSION PROFILE CHANGED IN RSV INFECTION}

MiRNAs have been intensively studied in the last decades since its discovery in Caenorhabditis elegans in 1993 (38). Whereas the majority of miRNAs have their own gene loci, there are $30 \%$ of miRNAs co-transcribed from the introns of protein-coding host genes $(39,40)$. Recent studies have uncovered that miRNA biogenesis can be regulated at multiple levels, including transcription, processing, modification by RNA editing, Argonaute loading, and RNA decay (41). There is complicated cross talk between miRNA synthesis and other cellular signaling pathways $(42,43)$. RSV could affect the biogenesis of miRNAs through G, NS1, and NS2 proteins by affecting cellular signal transduction $(17,44)$. RSV G proteins can upregulate host miRNA (let-7f, miR-24) expression to weaken the host antivirus response by inhibiting the formation of interferon$\lambda$ (IFN- $\lambda$ ) (45). In NHBE cells, the promoting role of NS1 and NS2 proteins in the expression of let-7i and miR-30b is mediated through interferon $-\beta$ (IFN- $\beta$ ) and nuclear factor- $\kappa \mathrm{B}(\mathrm{NF}-\kappa \mathrm{B})$ signaling separately (46). Similarly, RSV NS1 modifies miR-24 expression via transforming growth factor- $\beta$ (TGF- $\beta$ ) in A549 cells (47). It should be noted that RSV has cell-specific regulation of miRNA expression. Let-7b can be upregulated in dendritic cells (DCs), while the upregulation of let-7i and miR-30b requires viral replication (46).

RSV could significantly change the expression profile of miRNA in human bronchial epithelial cells, of which 24 miRNAs were greatly downregulated and two miRNAs were upregulated (48). In clinical samples and in vitro cell experiments, miRNA expression showed a distinct profile. The regulation of RSV on miRNAs was first observed in A549 cells, including elevated levels of let-7a, let-7f, miR-24, miR-36, miR-520, and miR-337 and decreased levels of miR-198, miR-224, and miR-595 (49). Recently, miR-29 has been identified to be upregulated by RSV NS1 protein not only in A549 cells but also in NPAs (50). Apart from A549 cells, normal epithelial cells and Hep-2 cells are the most common models of RSV infection. In RSV persistently infected Hep-2 cells, miRNA-146-5p, miR-let-7c-5p, miR-221, and miR-345-5p are differentially expressed (51). In addition to the cellular level, RSV infection also leads to changes in the expression of exosome miRNAs such as Let-7a, Let-7f, miR320a, miR-21, miR-4449, and miR-22 (52). MiRNAs in exosome, which is an important tool for intercellular communication, play an important role in pathogenesis and protection against diseases. In this way, the change of miRNA expression by RSV infection can not only act on the infected cells themselves but also regulate intercellular communication, thus affecting the local microenvironment.

Abnormal miRNA profiles have also been verified in clinical specimens such as nasal epithelium cytology brushings and peripheral blood from infants infected by RSV. Our former research found a significant alternation of miRNA expression profile in the peripheral blood of infants after RSV infection (53). The upregulated miRNAs include miR106b-5p, miR-181a-5p, miR-20b-5p, miR-342-3p, and miR-652$3 p$, while the downregulated including miR-122-5p, miR-320e,
miR-320d, miR-877-5p, miR-92b-5p, and let-7c-5p. Considering the different expression levels of miR-125a and miR-429 in NPAs of children with different severity of RSV infection (21), miRNAs may become potential biomarkers for the diagnosis and treatment of RSV infection. Furthermore, an increasing number of miRNAs (Figure 1) are confirmed to directly regulate leukotriene levels by targeting proteins associated with AA metabolism $(24,54,55)$. The majority of miRNAs mentioned above were involved in pathways related to the immune and inflammatory responses such as macrophage polarization states (56-58), which is closely associated with the balance between leukotriene synthesis and regression and the following severe airway inflammation (59-61).

\section{THE REGULATORY FUNCTIONS OF mIRNAs RELATED TO LEUKOTRIENE SYNTHESIS ON THE INFLAMMATORY RESPONSE DURING RSV INFECTION}

Many miRNAs are directly or indirectly related to leukotriene synthesis, however, only a few of them have been confirmed to be significantly changed and involved in the regulation of leukotriene synthesis in RSV infection. We matched the function in arachidonic acid metabolism and expression during RSV infection of these miRNAs (miR-125a, miR-19a, let-7, miR-146a, miR-30a-5p, miR-16-5p, miR-26b, miR-21, miR-143) together and summarized in Table 1. Next, we focus on the expression and role of several kinds of miRNA which are widely involved in the regulation of inflammatory pathways after RSV infection.

\section{MiR-19a}

MiR-19a is a member of the miR-17-92 cluster which contains 6 miRNAs (miR-17, miR-18a, miR-19a, miR-19b, miR-20a, and miR-92) and is a potential regulator of several proliferationrelated genes. MiR-19a is overexpressed in both asthma cases and RSV-infected patients. In asthma, miR-19a can promote the production of Th2 cytokine IL-13 by directly targeting PTEN, a signal transduction inhibitor suppressor of cytokine signaling 1 (SOCS1), and deubiquitinase A20 $(73,74)$. Similarly with leukotriene, IL-13 is a key driver of airway inflammation, inducing epithelial cell proliferation and mucus production, airway hyperreactivity, and eosinophil recruitment. RSV infection stimulates group 2 innate lymphoid cells (ILC2) to express a higher level of IL-13 through the thymic stromal lymphatic hormone in the mouse model (75). Interestingly, CysLTs induce ILC2 cell migration and promote the production of IL-13, and IL-13 increased bronchial smooth muscle cell (BSMC) CysLT1R protein expression in effect related to its concentration in in vitro experiments $(76,77)$.

In a prior study, miR-17-92 controls the proliferation and survival of CD8 T-cells by suppressing the expression of the phosphatase and tensin homolog (PTEN) (78). The decreasing formation of PTEN leads to the activation of the PI3K-AktmTOR signaling pathway, which causes memory differentiation inhibition (79). Moreover, both fatty acid synthesis and fatty acid 
TABLE 1 | Summary-miRNAs influencing the AA metabolism and abnormal expressed in RSV infection.

\begin{tabular}{|c|c|c|c|c|c|c|c|c|c|}
\hline \multirow[t]{2}{*}{ miRNA } & \multicolumn{4}{|c|}{ miRNAs and AA metabolism } & \multicolumn{4}{|c|}{ RSV infection and miRNAs } & \multirow[b]{2}{*}{ Year } \\
\hline & Target gene & Cell type & Reference & Year & $\begin{array}{c}\text { Expression } \\
\text { level }\end{array}$ & Method & Sample source & Reference & \\
\hline hsa-miR-125b & 5-LOX & $\begin{array}{l}\text { Monocytes } \\
\text { (MM6 cells), } \\
\text { T- } \\
\text { lymphocytes }\end{array}$ & (62) & (2015) & $\downarrow$ & $\begin{array}{l}\text { miRNA } \\
\text { microarray, } \\
\text { qPCR }\end{array}$ & $\begin{array}{l}\text { nasal mucosal } \\
\text { specimens }\end{array}$ & $(21)$ & $(2015)$ \\
\hline hsa-miR-19a & 5-LOX & $\begin{array}{l}\text { Monocytes } \\
\text { (MM6 cells), } \\
\text { T- } \\
\text { lymphocytes }\end{array}$ & (62) & (2015) & $\uparrow$ & $\begin{array}{l}\text { miRNA } \\
\text { microarray }\end{array}$ & $\begin{array}{l}\text { nasal mucosal } \\
\text { specimens }\end{array}$ & $(21)$ & $(2015)$ \\
\hline let-7 & 5-LOX & $\begin{array}{l}\text { Endothelial } \\
\text { cells (ECs) of } \\
\text { mouse model }\end{array}$ & (63) & (2017) & $\uparrow$ & $\begin{array}{l}\text { miRNA } \\
\text { microarray }\end{array}$ & peripheral blood & (53) & $(2017)$ \\
\hline hsa-miR-146a & FLAP,COX-2 & Lung cancer & $(64,65)$ & (2014) (2018) & $\uparrow$ & qPCR & Hep2 & (51) & (2018) \\
\hline hsa-miR-30a-5p & COX-2 & $\begin{array}{l}\text { Gastric } \\
\text { cancer }\end{array}$ & $(66)$ & (2017) & $\uparrow$ & NGS, qPCR & $\begin{array}{l}\text { moDCs from } \\
\text { human PBMCs }\end{array}$ & $(67)$ & (2018) \\
\hline hsa-miR-16-5p & COX-2 & $\begin{array}{l}\text { Cervical } \\
\text { cancer, } \\
\text { Hepatocellular } \\
\text { carcinoma }\end{array}$ & $(55,68)$ & (2005) (2012) & $\uparrow$ & $\begin{array}{l}\text { miRNA, } \\
\text { microarray, } \\
\text { qPCR }\end{array}$ & $\begin{array}{l}\text { nasal mucosal } \\
\text { specimens }\end{array}$ & $(21)$ & $(2015)$ \\
\hline hsa-miR-26b & COX-2 & $\begin{array}{l}\text { Nasopharyngeal } \\
\text { epithelial } \\
\text { cancer }\end{array}$ & (69) & (2010) & $\uparrow$ & $\begin{array}{l}\text { miRNA, } \\
\text { microarray, } \\
\text { qPCR }\end{array}$ & PBMCs & (49) & (2012) \\
\hline hsa-miR-143 & COX-2 & $\begin{array}{l}\text { Amnion } \\
\text { mesenchymal } \\
\text { cells }\end{array}$ & $(70)$ & (2011) & $\downarrow$ & $\begin{array}{l}\text { multiplex } \\
\text { qPCR array }\end{array}$ & NHBES & (48) & (2012) \\
\hline hsa-miR-21 & 15-PGDH & Cholangiocarcinom & n $\quad(71)$ & (2014) & $\uparrow$ & NGS, qPCR & $\begin{array}{l}\text { exosomes derived } \\
\text { from RSV-infected } \\
\text { A549/SAE cells }\end{array}$ & (72) & (2012) \\
\hline
\end{tabular}

uptake are stimulated in response to mTOR signaling, including polyunsaturated fatty acids, which are the immediate precursors of many lipids (80). In the NPAs of infants infected with RSV, the results of microarray support the upregulation of miR-19a$3 p$ in the severe disease subgroup (21). We previously found that miR-106b-5p, a paralog of the miR-17-92 cluster family, was significantly increased in the peripheral blood of infants with RSV infection (53). Consistent with the function of miR-19a, miR-106b regulates the PI3K-Akt pathway by suppressing PTEN (81). MiRNA-19a and miR-106b may play an activator role in leukotriene synthesis.

\section{miR-125a}

Also in the NPAs of infants infected with RSV, the expression of miR-125a in the mild and moderate disease subgroups was downregulated, while it was not expressed in the severe disease subgroup (21). Previous studies have promoted that miR-125a and miR-125b constitutively activate the NF- $\kappa$ B pathway by targeting the tumor necrosis factor alpha-induced protein 3 , and miR-125a may participate in the self-regulatory loop of miR$125 \mathrm{~b}$ and NF- $\kappa \mathrm{B}$ (82). Prior research substantiates the belief that the NF- $\kappa \mathrm{B}$ pathway plays a central role in mediating airway inflammation induced by RSV, and RSV can regulate miRNAs by the NF- $\kappa$ B pathway $(46,83)$.

\section{miR-146a}

The expression of miR-146a is significantly altered by RSV infection, which could also be mediated by the activation of the NF- $\kappa \mathrm{B}$ pathway $(51,84)$. The academic community has extensively explored the anti-inflammatory functions of miR$146 \mathrm{a}$ in the airway. Pro-inflammatory cytokines such as IL-1 $\beta$, TNF- $\alpha$, and IFN- $\gamma$ can induce the expression of miR-146a in human airway smooth muscle cells (85). MiR-146a can negatively regulate inflammatory gene levels in numerous cell types, including monocytes, fibroblasts, and endothelial, airway smooth muscle, and epithelial cells (85-87). Based on these studies, RSV infection downregulates the expression of miR-146a which may play a key role in impairing inhibitory effects on inflammatory pathways such as leukotriene synthesis. For example, miR-146a enhances M2 macrophage polarization by activating peroxisome proliferator-activated receptors $\gamma$ (88), while it negatively regulates TLR4 signaling which plays an essential role in the regulation of M1 macrophage polarization (89).

\section{Let-7 Family}

Let-7 family miRNAs play an important role in inhibiting host innate immunity and promoting replication during RSV infection $(17,45,52)$. RSV induces let-7 family miRNA levels. We have previously found that let-7c was increased by RSV in A549 cells and peripheral blood of infants (53). RSV may enhance 
nuclear transcription factors associated with let-7 synthesis by activating MAPK pathways through TLR signaling (90-92). Ras-ERK/MAPK signaling is repressed by let-7 miRNAs in humans and other species (92). This phenomenon may be a conserved regulatory mechanism. The overexpression of let7 miRNAs may be one of the negative feedback loops for regulating MAPK. Furthermore, MAPK is associated with 5-LOX enzyme activity. p38 MAPK can be rapidly activated by RSV. Activated p38 phosphorylates and stimulates downstream kinase to phosphorylate 5-lipoxygenase. RSV is a potent inducer of NF$\mathrm{kB}$ and p38 MAPK phosphorylation in A549 cells (90, 93). RSV induces high-mobility group box 1 (HMGB1) to release from human airway epithelial cells via NF-kB and TLR4 signaling pathways. Then, HMGB1 activates p38 MAPK and triggers the release of pro-inflammatory mediators (94). In an ovalbuminsensitized murine model of asthma, let-7 miRNA downregulated IL-13 and relieved allergic airway inflammation (20).

\section{miR-21}

MiR-21, which can be secreted by exosomes, is one of the most highly expressed members of the small non-coding miRNA family in many cell types and tissues. It is accepted as an activator of regeneration processes in tissue damage repair and tumor growth (63). In addition, miR-21 may be a common biomarker of inflammation-related diseases (95). Induced by many pro-inflammatory stimuli including pathogen-associated molecular patterns (PAMP) and dangerassociated molecular patterns (DAMP), miR-21 subsequently triggers the inflammatory circuit and promotes the function of the immune system. It may be a negative regulation of the inflammatory process and an important switch for dispelling inflammation $(96,97)$. In RSV-infected cells, there was a significant upregulation in the composition of exosome miR21(72, 98). Exosomes released from virus-infected A549 cells can alter innate immune responses through the induction of pro-inflammatory mediators. Antagonistic miR-21 treatment can inhibit eosinophil inflammation and AHR in RSV-induced steroid-insensitive mouse airway allergic disease models (99). Therefore, miR-21 may be a key signal to regulate the balance and transition between pro-inflammatory and immune activation. The regulatory roles of miR-21 on the synthesis of leukotrienes are described below.

\section{miR-26b and miR-16}

These miRNAs are widely involved in the inflammation reaction induced by RSV infection. Microarray and NGS of RSV infection specimens have shown an obvious change in expression profile (21, 67). Peripheral blood mononuclear cells (PBMCs) in children with RSV infection had higher miR-26b levels, while miR-26b induced downregulation of the TLR4 signal in vitro (100). Similarly, RSV induced miR-26 in A549 cells (49). Besides, miR-26a is correlated with hypertrophic human airway smooth muscle cells, which is one of the hallmarks of airway remodeling in severe asthma (101). In a study aiming to establish whether miRNAs could be used to characterize or subtype asthmatic patients, circulating miR-16 was one of the most predictive of allergic and asthmatic status (102). Likewise, miR-16 upregulated by RSV may participate in the formation of AHR.

\section{LINKAGES BETWEEN miRNAs AND LEUKOTRIENES DURING OTHER RESPIRATORY VIRUS INFECTIONS}

Leukotrienes are also believed to contribute to the pathophysiology of respiratory infection by other viruses such as influenza, rhinovirus (RV), metapneumovirus (HMPV), and adenovirus. The sporadic association between leukotrienes and miRNAs has been reported during infection of these viruses. We included related studies in Table 2. Compared to RSV, influenza may increase leukotriene concentrations by inducing the 5-LOX pathway (103). Similar to RSV, the miRNA expression profile of host cells is significantly changed by influenza (111). Among these miRNAs, let-7, miR-21, and miR-29 have connections with AA metabolism and miR-29 activates COX-2 through epigenetic changes during influenza A infection (104). Alveolar lavage fluid of RV infection patients contains higher cysLT levels than the control group (112). This may be associated with the induction of 5-LOX, FLAP, and COX-2 (105). However, there are few reporters about leukotriene synthesis-related miRNAs except RV-increasing airway secretory miR-155 in young children (106). MiR-155 is associated with prostaglandin metabolism in cancer, but its roles in leukotriene synthesis have not been investigated yet. As to HMPV, which shows common symptoms of wheezing like RSV, one study has shown that bronchiolitis children infected with HMPV have higher leukotriene levels in blood and urine than the control group (107). However, the roles of 5-LOX and COX-2 in HMPV infection are still unknown. Nonetheless, montelukast, a selective CysLT1R antagonist, has been used to treat HMPV infection of hospitalized young children (113). A high-throughput sequencing study of HMPVinfected A549 cells shows upregulation of let-7f (108). Both upregulation of leukotrienes and let-7f in HMPV infection are consistent with RSV infection. This remains to be established. Unlike these RNA viruses, adenovirus reduces the release of arachidonic acid by inhibiting the translocation of cPLA2 to membranes (109). MiRNA (include miR-125, miR-19a, miR-191) levels in adenovirus-infected cells fluctuate in distinct stages (110). Whether or not miRNAs changed by these viruses are involved with leukotriene synthesis during infection still needs further investigations.

\section{miRNAs REGULATING THE SYNTHESIS OF LEUKOTRIENES}

\section{miRNAs and Lipoxygenase Pathway Expression and Activity of 5-LOX}

During RSV infection, a damaged or inflamed bronchial epithelium synthesizes a higher level of leukotrienes by inducing 5-LOX (114), the most critical enzyme of leukotriene synthesis. Recent studies have demonstrated various types of miRNAs involved in the regulation of 5-LOX. For example, miR-219-2 can directly interact with the $3^{\prime}$ untranslated region ( $3^{\prime}$-UTR) 


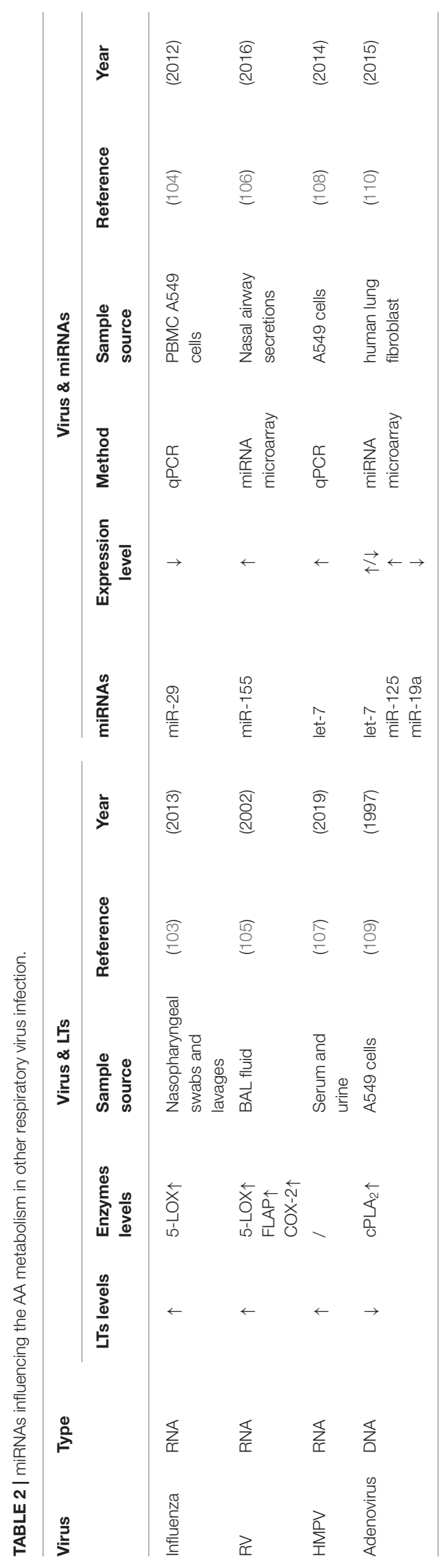

of 5-LOX to downregulate the expression of 5-LOX mRNA in macrophages (115). Similarly, overexpression of miR-216a$3 p$ in human colorectal cancer cell lines can directly bind to the $3^{\prime}$-UTR, causing the same effect on 5-LOX (116). MiR-19a$3 p$ and miR-125-5p, which are abnormally expressed in RSV infection (21), have also been identified to directly regulate the expression of 5-LOX protein without affecting 5-LOX mRNA in monocyte line MM6 induced in vitro (62). MiR-674-5p can attenuate concanavalin A-induced liver injury in mice by downregulating 5-LOX (117). In rats with focal cerebral ischemia and reperfusion, miRNA-193b-3p can alleviate the injury by inhibiting the expression of 5-LOX (118). In a deficient mouse model, a decrease of let-7 miRNAs led to the upregulation of 5-LOX and subsequent aberrant activation of the leukotriene biosynthesis pathway in Drosha mutants (119). MiR-21 can activate the signal transduction downstream of TGF- $\beta$ (120), while the combination of TGF- $\beta$ and 1,25-dihydroxyvitamin D3 (VD3) can significantly increase the levels of 5-LOX in human monocytes (121). Accordingly, RSV can upregulate the level of leukotrienes by upregulating 5-LOX through the abnormal expression of miRNAs.

The activity of intracellular 5-LOX is strictly controlled by $\mathrm{Ca} 2+$, ATP, redox state, and phosphorylation $(25,122)$. However, nearly all of these factors can be affected by RSV $(90,123)$. Ca2+ regulates 5-LOX activity through the C2-like domain. Besides, $\mathrm{Ca} 2+$ increases the activation of MAPK and facilitates 5-LOX migrating to the nuclear membrane, which is necessary for leukotriene synthesis. By activating the p38 MAPK signal, RSV can directly activate 5 -LOX by phosphorylation in monocytes (MM6) and polymorphonuclear leukocytes (PMNL) (124). In this process, miRNAs such as let-7 and miR-21 play a pivotal role $(125,126)$. Taken together, these examples reveal the possible mechanism of how miRNAs control the enzymatic activity of 5-LOX in RSV infection.

\section{Expression of FLAP}

Abnormal levels of miRNAs and FLAP have been welldocumented in RSV infection. Besides, recent studies have found that miRNAs can suppress the formation of FLAP, one of the most critical factors of the 5-LOX catalysis function. MiR-135a and miR-199a-5p can target the $3^{\prime}$-UTR of mRNA to negatively regulate the expression of FLAP. Therefore, in hypoxia-induced endothelial cells, the downregulation of miR-135a and miR-199a$5 p$ can increase the expression of FLAP (127). Another study has confirmed that hypermethylation of the miR-146a promoter leads to decreased expression of FLAP and leukotrienes in lung cancer cells, also by directly targeting the $3^{\prime}$-UTR of FLAP (64).

\section{Expression of 12/15-LOX}

The lipoxygenase pathway can also synthesize SPMs via 5-LOX and 12/15-LOX. SPMs are endogenous regulators of infection and inflammation, with a wide range of pro-inflammatory effects, such as inhibition of neutrophil and eosinophil chemotaxis, vascular adhesion, and transendothelial and transepithelial migration (65, 128-130). MiRNAs targeting 12/15-LOX may also contribute to the imbalanced inflammation in RSV infection. In a mouse hippocampal cell line, miR-181b directly binds to 
12/15-LOX 3'-UTR, thereby negatively regulating 12/15-LOX expression (131). By inhibiting the expression of 12/15-LOX, miR-106a could reverse the effect that was induced by high glucose in the diabetic peripheral neuropathy mouse model (131). Moreover, overexpression of miR-219-2 in macrophages can increase 15-LOX and 12-LOX mRNA expression but decrease the expression of $\mathrm{LTA}_{4} \mathrm{H}$ (115). Recently, a study found that eicosapentaenoic acid's metabolism of 15-LOX promotes the expression of miR-101, thus inhibiting the COX2 pathway in colon cancer, which also implies the complicated links among miRNA, LOX pathway, and COX pathway (132).

\section{miRNAs and COX Pathway}

Another vital way to increase leukotrienes is to inhibit the COX pathway. Prostaglandins (PGs), synthesized by AA through the COX pathway, are the most widely studied inflammation mediators by far. There is strong evidence that RSV infection can induce COX-2 with the concomitant production of PGs in AECs $(37,133)$. COX-2 is an inducible enzyme for PG synthesis, which is upregulated in inflammatory cells and thus induces an increase of PGs and inflammatory damage (134). Evidence for miRNAs controlling the expression of COX-2 is abundant. MiR-16 can complement with the AU-rich region of 3 UTR of COX-2, thus changing the stability of COX-2 mRNA (135). Overexpression of miR-216a-3p in human colorectal cancer cell lines can also inhibit the expression of COX-2(116). Similarly, both COX2 and FLAP were downregulated by hypermethylation of the miR-146a promoter through directly interacting with the 3 ' UTR of the target mRNA (64). A study showed that $\mathrm{NAD}^{+}$-linked 15-hydroxyprostaglandin dehydrogenase (15-PGDH), which is part of the COX-2/PGE2 signaling pathway, was identified as a target of miR-21 in cholangiocarcinoma (71). In addition, miRNA can also inhibit the expression of COX-2 by reducing the level of the RNA-binding protein HUR in human hepatoma cells (68). Other miRNAs, such as miR-26, miR-30, miR-101, miR-137, miR-143, miR-144, miR-146a, miR-199a, and miR216 , are successively identified to modulate the COX pathway $(24,55,66,67,69,70)$, although their detailed mechanism has not been previously reported.

\section{REFERENCES}

1. Shi T, McAllister DA, O'Brien KL, Simoes EAF, Madhi SA, Gessner BD, et al. Global, regional, and national disease burden estimates of acute lower respiratory infections due to respiratory syncytial virus in young children in 2015: a systematic review and modelling study. Lancet. (2017) 390:946-58. doi: 10.1016/S0140-6736(17)30938-8

2. Griffiths C, Drews SJ, Marchant DJ. Respiratory syncytial virus: infection, detection, and new options for prevention and treatment. Clin Microbiol Rev. (2017) 30:277-319. doi: 10.1128/CMR.00010-16

3. Thompson WW, Shay DK, Weintraub E, Brammer L, Cox N, Anderson LJ, et al. Mortality associated with influenza and respiratory syncytial virus in the United States. JAMA. (2003) 289:179-86. doi: 10.1001/jama.289.2.179

4. Friedman D, Fryzek J, Jiang X, Bloomfield A, Ambrose CS, Wong PC. Respiratory syncytial virus hospitalization risk in the second year of life by specific congenital heart disease diagnoses. PLOS ONE. (2017) 12:e0172512. doi: 10.1371/journal.pone.0172512

\section{CONCLUSION}

The expression of miRNAs and leukotrienes changed dramatically after RSV infection. Overexpressed leukotrienes are closely related to AHR, mucous cell metaplasia, leukocyte aggregation, and airway barrier destruction following RSV infection. To explore the mechanism of action of miRNAs in RSV infection is important for developing strategies to restore the level of leukotrienes. MiRNAs can modulate the synthesis of leukotrienes by participating in posttranscriptional regulation of several key enzymes and associated activating proteins, which results in an imbalance between pro-inflammatory and pro-resolving mediators. Moreover, miRNAs can be secreted through the exosome and they have cellular specificity, so they can widely regulate the immune response after RSV infection. In summary, we described miRNAs that are abnormally expressed both in RSV infection and related to leukotriene synthesis, which may have important implications in the excessive inflammation of RSV infection and provide a potential therapeutic approach for the reasonable regulation of leukotriene expression after RSV infection.

\section{AUTHOR CONTRIBUTIONS}

$\mathrm{ZL}, \mathrm{PF}$, and DZ participated in writing the paper and collecting the articles and contributed for the linguistic revision of the manuscript. DZ guided the writing and editing of the article. MC and YX collected the references and revised the review. All authors contributed to the article and approved the submitted version.

\section{FUNDING}

This work was supported by the National Natural Science Foundation of China (No. 81670007).

\section{ACKNOWLEDGMENTS}

The authors thank all participants in the study.

5. Bennett MV, McLaurin K, Ambrose C, Lee HC. Population-based trends and underlying risk factors for infant respiratory syncytial virus and bronchiolitis hospitalizations. PLoS ONE. (2018) 13:e0205399. doi: 10.1371/journal.pone.0205399

6. Caidi H, Miao C, Thornburg NJ, Tripp RA, Anderson LJ, Haynes LM. Anti-respiratory syncytial virus (RSV) G monoclonal antibodies reduce lung inflammation and viral lung titers when delivered therapeutically in a BALB/c mouse model. Antivir Res. (2018) 154:149-57. doi: 10.1016/j.antiviral.2018.04.014

7. Hu M, Bogoyevitch MA, Jans DA. Impact of respiratory syncytial virus infection on host functions: implications for antiviral strategies. Physiol Rev. (2020)100:1527-94. doi: 10.1152/physrev.00030.2019

8. Walker JA, McKenzie ANJ. TH2 cell development and function. Nat Rev Immunol. (2018) 18:121-33. doi: 10.1038/nri.2017.118

9. Stein RT, Sherrill D, Morgan WJ, Holberg CJ, Halonen M, Taussig LM, et al. Respiratory syncytial virus in early life and risk of wheeze and allergy by age 13 years. Lancet. (1999) 354:541-5. doi: 10.1016/S0140-6736(98)10321-5 
10. Rudd PA, Thomas BJ, Zaid A, MacDonald M, Kan-o K, Rolph MS, et al. Role of human metapneumovirus and respiratory syncytial virus in asthma exacerbations: where are we now? Clin Sci. (2017) 131:1713-21. doi: 10.1042/CS20160011

11. Han J, Jia Y, Takeda K, Shiraishi Y, Okamoto M, Dakhama A, et al. Montelukast during primary infection prevents airway hyperresponsiveness and inflammation after reinfection with respiratory syncytial virus. Am J Respir Crit Care Med. (2010) 182:455-63. doi: 10.1164/rccm.200912-1811OC

12. Bartel DP. MicroRNAs: target recognition and regulatory functions. CELL. (2009) 136:215-33. doi: 10.1016/j.cell.2009.01.002

13. Krol J, Loedige I, Filipowicz W. The widespread regulation of microRNA biogenesis, function and decay. Nat Rev Genet. (2010) 11:597-610. doi: $10.1038 / \mathrm{nrg} 2843$

14. Rebane A, Akdis CA. MicroRNAs: essential players in the regulation of inflammation. J Allergy Clin Immun. (2013) 132:15-26. doi: 10.1016/j.jaci.2013.04.011

15. Globinska A, Pawelczyk M, Kowalski ML. MicroRNAs and the immune response to respiratory virus infections. Expert Rev Clin Immunol. (2014) 10:963-71. doi: 10.1586/1744666X.2014.913482

16. Qi F, Wang D, Liu J, Zeng S, Xu L, Hu H, et al. Respiratory macrophages and dendritic cells mediate respiratory syncytial virus-induced IL-33 production in TLR3- or TLR7-dependent manner. Int Immunopharmacol. (2015) 29:408-15. doi: 10.1016/j.intimp.2015.10.022

17. Feng S, Zeng D, Zheng J, Zhao D. MicroRNAs: mediators and therapeutic targets to airway hyper reactivity after respiratory syncytial virus infection. Front Microbiol. (2018) 9:2177. doi: 10.3389/fmicb.2018.02177

18. Xie N, Cui H, Banerjee S, Tan Z, Salomao R, Fu M, et al. miR-27a regulates inflammatory response of macrophages by targeting IL-10. J Immunol. (2014) 193:327-34. doi: 10.4049/jimmunol.1400203

19. Cho S, Wu C, Yasuda T, Cruz LO, Khan AA, Lin L, et al. miR-23 27 24 clusters control effector T cell differentiation and function. J Exp Med. (2016) 213:235-49. doi: 10.1084/jem.20150990

20. Kumar M, Ahmad T, Sharma A, Mabalirajan U, Kulshreshtha A, Agrawal A, et al. Let-7 microRNA-mediated regulation of IL-13 and allergic airway inflammation. J Allergy Clin Immun. (2011) 128:1077-85.e10. doi: 10.1016/j.jaci.2011.04.034

21. Inchley CS, Sonerud T, Fjærli HO, Nakstad B. Nasal mucosal microRNA expression in children with respiratory syncytial virus infection. BMC Infect Dis. (2015) 15:150. doi: 10.1186/s12879-015-0878-z

22. Zhang Y, Shao L. Decreased microRNA-140-5p contributes to respiratory syncytial virus disease through targeting Toll-like receptor 4. Exp Ther Med. (2018) 16:993-99. doi: 10.3892/etm.2018.6272

23. Wang Z, Filgueiras LR, Wang S, Serezani APM, Peters-Golden M, Jancar $S$, et al. Leukotriene B4 enhances the generation of proinflammatory microRNAs to promote MyD88-dependent macrophage activation. J Immunol. (2014) 192:2349-56. doi: 10.4049/jimmunol.1302982

24. Saul MJ, Emmerich AC, Steinhilber D, Suess B. Regulation of eicosanoid pathways by MicroRNAs. Front Pharmacol. (2019) 10:824. doi: 10.3389/fphar.2019.00824

25. Ford-Hutchinson AW, Gresser M, Young RN. 5-Lipoxygenase. Annu Rev Biochem. (1994) 63:383-417. doi: 10.1146/annurev.bi.63.070194.0 02123

26. Funk CD. Prostaglandins and leukotrienes: advances in eicosanoid biology. Science. (2001) 294:1871-5. doi: 10.1126/science.294.5548.1871

27. Peters-Golden M, Henderson WJ. Leukotrienes. N Engl J Med. (2007) 357:1841-54. doi: 10.1056/NEJMra071371

28. Dennis EA, Norris PC. Eicosanoid storm in infection and inflammation. Nat Rev Immunol. (2015) 15:511-23. doi: 10.1038/nri3859

29. Dimova-Yaneva D, Russell D, Main M, Brooker RJ, Helms PJ. Eosinophil activation and cysteinyl leukotriene production in infants with respiratory syncytial virus bronchiolitis. Clin Exp Allergy. (2004) 34:555-8. doi: 10.1111/j.1365-2222.2004.1918.x

30. Kim CK, Koh JY, Han TH, Kim DK, Kim BI, Koh YY. Increased levels of BAL cysteinyl leukotrienes in acute [corrected] RSV bronchiolitis. Acta Paediatr. (2006) 95:479-85. doi: 10.1080/08035250600554268

31. Da Dalt L, Callegaro S, Carraro S, Andreola B, Corradi M, Baraldi E. Nasal lavage leukotrienes in infants with RSV bronchiolitis. Pediatr Allergy Immunol. (2007) 18:100-4.
32. Oymar K, Halvorsen T, Aksnes L. Mast cell activation and leukotriene secretion in wheezing infants. Relation to respiratory syncytial virus and outcome. Pediat Allerg Imm-UK. (2006) 17:37-42. doi: 10.1111/j.1399-3038.2005.00345.x

33. Sastre B, García-García ML, Calvo C, Casas I, Rodrigo-Muñoz JM, Cañas JA, et al. Immune recovery following bronchiolitis is linked to a drop in cytokine and LTC4 levels. Pediatr Res. (2020) 87:581-7. doi: 10.1038/s41390-019-0606-2

34. Sun L, Chen A, Yang Z, Chen JJ, Guan W, Wu J, et al. Respiratory syncytial virus induces leukotriene $\mathrm{C} 4$ synthase expression in bronchial epithelial cells. Respirology. (2013) 18:40-6. doi: 10.1111/resp.12188

35. Behera AK, Kumar M, Matsuse H, Lockey RF, Mohapatra SS. Respiratory syncytial virus induces the expression of 5-lipoxygenase and endothelin1 in bronchial epithelial cells. Biochem Bioph Res Co. (1998) 251:704-9. doi: 10.1006/bbrc.1998.9537

36. Musiyenko A, Correa L, Stock N, Hutchinson JH, Lorrain DS, Bain G, et al. A novel 5-lipoxygenase-activating protein inhibitor, AM679, reduces inflammation in the respiratory syncytial virus-infected mouse eye. Clin Vaccine Immunol. (2009) 16:1654-9. doi: 10.1128/CVI.00220-09

37. Richardson JY, Ottolini MG, Pletneva L, Boukhvalova M, Zhang S, Vogel $\mathrm{SN}$, et al. Respiratory syncytial virus (RSV) infection induces cyclooxygenase 2: a potential target for RSV therapy. J Immunol. (2005) 174:4356-64. doi: 10.4049/jimmunol.174.7.4356

38. Wightman B, Ha I, Ruvkun G. Posttranscriptional regulation of the heterochronic gene lin-14 by lin- 4 mediates temporal pattern formation in C. elegans. Cell. (1993) 75:855-62. doi: 10.1016/0092-8674(93)90530-4

39. Lin S, Gregory RI. MicroRNA biogenesis pathways in cancer. Nat Rev Cancer. (2015) 15:321-33. doi: 10.1038/nrc3932

40. Lagos-Quintana M, Rauhut R, Lendeckel W, Tuschl T. Identification of novel genes coding for small expressed RNAs. Science. (2001) 294:853-8. doi: $10.1126 /$ science. 1064921

41. Ha M, Kim VN. Regulation of microRNA biogenesis. Nat Rev Mol Cell Bio. (2014) 15:509-24. doi: 10.1038/nrm3838

42. Di Leva G, Garofalo M, Croce CM. MicroRNAs in Cancer. Ann Rev Pathol Mech Dis. (2014) 9:287-14. doi: 10.1146/annurev-pathol-012513-104715

43. Olejniczak M, Kotowska-Zimmer A, Krzyzosiak W. Stress-induced changes in miRNA biogenesis and functioning. Cell Mol Life Sci. (2018) 75:177-91. doi: 10.1007/s00018-017-2591-0

44. Atherton LJ, Jorquera PA, Bakre AA, Tripp RA. Determining immune and miRNA biomarkers related to respiratory syncytial virus (RSV) vaccine types. Front Immunol. (2019) 10:2323. doi: 10.3389/fimmu.2019.02323

45. Bakre A, Harcourt J, Haynes L, Anderson L, Tripp R. The central conserved region (CCR) of respiratory syncytial virus (RSV) G protein modulates host miRNA expression and alters the cellular response to infection. Vaccines. (2017) 5:16. doi: 10.3390/vaccines5030016

46. Thornburg NJ, Hayward SL, Crowe JJE. Respiratory syncytial virus regulates human microRNAs by using mechanisms involving beta interferon and NF-кB. MBIO. (2012) 3:e00220-12. doi: 10.1128/mBio.00220-12

47. Bakre A, Wu W, Hiscox J, Spann K, Teng MN, Tripp RA. Human respiratory syncytial virus non-structural protein NS1 modifies miR-24 expression via transforming growth factor- $\beta$. J Gen Virol. (2015) 96:3179-91. doi: 10.1099/jgv.0.000261

48. Othumpangat S, Walton C, Piedimonte G. MicroRNA-221 modulates RSV replication in human bronchial epithelium by targeting NGF expression. PLoS ONE. (2012) 7:e30030. doi: 10.1371/journal.pone.0030030

49. Bakre A, Mitchell P, Coleman JK, Jones LP, Saavedra G, Teng M, et al. Respiratory syncytial virus modifies microRNAs regulating host genes that affect virus replication. J Gen Virol. (2012) 93:2346-56. doi: 10.1099/vir.0.044255-0

50. Gao L, Mo S, Xie J, Chen S, Wen X, Long X, et al. Respiratory syncytial virus nonstructural protein 1 downregulates glucocorticoid receptor expression through miR-29a. J Allergy Clin Immunol. (2019) 144:854-7.e6. doi: 10.1016/j.jaci.2019.05.014

51. Eilam-Frenkel B, Naaman H, Brkic G, Veksler-Lublinsky I, Rall G, Shemer-Avni Y, et al. MicroRNA 146-5p, miR-let-7c-5p, miR-221 and miR-345-5p are differentially expressed in Respiratory Syncytial Virus (RSV) persistently infected HEp-2 cells. Virus Res. (2018) 251:34-9. doi: 10.1016/j.virusres.2018.05.006 
52. Wu W, Choi E, Lee I, Lee YS, Bao X. Non-coding RNAs and their role in respiratory syncytial virus (RSV) and human metapneumovirus (hMPV) infections. Viruses. (2020) 12:345. doi: 10.3390/v12030345

53. Wang S, Liu P, Yang P, Zheng J, Zhao D. Peripheral blood microRNAs expression is associated with infant respiratory syncytial virus infection. Oncotarget. (2017) 8:96627-35. doi: 10.18632/oncotarget.19364

54. Lutz CS, Cornett AL. Regulation of genes in the arachidonic acid metabolic pathway by RNA processing and RNA-mediated mechanisms. Wiley Interdiscip Rev RNA. (2013) 4:593-605. doi: 10.1002/wrna.1183

55. Ochs MJ, Steinhilber D, Suess B. MicroRNAs-novel therapeutic targets of eicosanoid signalling. Basic Clin Pharmacol Toxicol. (2014) 114:92-6. doi: $10.1111 /$ bcpt.12116

56. Murray PJ, Wynn TA. Protective and pathogenic functions of macrophage subsets. Nat Rev Immunol. (2011) 11:723-737. doi: 10.1038/nri3073

57. Essandoh K, Li Y, Huo J, Fan G. MiRNA-mediated macrophage polarization and its potential role in the regulation of inflammatory response. Shock. (2016) 46:122-31. doi: 10.1097/SHK.0000000000000604

58. Werz O, Gerstmeier J, Libreros S, De la Rosa X, Werner M, Norris PC, et al. Human macrophages differentially produce specific resolvin or leukotriene signals that depend on bacterial pathogenicity. Nat Commun. (2018) 9:59. doi: 10.1038/s41467-017-02538-5

59. Li H, Jiang $\mathrm{T}$, Li M, Zheng $\mathrm{X}$, Zhao G. Transcriptional regulation of macrophages polarization by MicroRNAs. Front Immunol. (2018) 9:1175. doi: 10.3389/fimmu.2018.01175

60. Dalli J, Serhan CN. Specific lipid mediator signatures of human phagocytes: microparticles stimulate macrophage efferocytosis and pro-resolving mediators. Blood. (2012) 120:e60-e72. doi: 10.1182/blood-2012-04-423525

61. Levy BD, Abdulnour RE, Tavares A, Brüggemann TR, Norris PC, Bai $\mathrm{Y}$, et al. Cysteinyl maresins regulate the prophlogistic lung actions of cysteinyl leukotrienes. J Allergy Clin Immun. (2020) 145:335-44. doi: 10.1016/j.jaci.2019.09.028

62. Busch S, Auth E, Scholl F, Huenecke S, Koehl U, Suess B, et al. 5-lipoxygenase is a direct target of miR-19a-3p and miR-125b-5p. J Immunol. (2015) 194:1646-53. doi: 10.4049/jimmunol.1402163

63. Sheetz M. A tale of two states: normal and transformed, with and without rigidity sensing. Annu Rev Cell Dev Biol. (2019) 35:169-90. doi: 10.1146/annurev-cellbio-100818-125227

64. Iacona JR, Monteleone NJ, Lutz CS. miR-146a suppresses 5-lipoxygenase activating protein (FLAP) expression and leukotriene B4 production in lung cancer cells. Oncotarget. (2018) 9:26751-69. doi: 10.18632/oncotarget.25482

65. Romano M, Cianci E, Simiele F, Recchiuti A. Lipoxins and aspirin-triggered lipoxins in resolution of inflammation. Eur J Pharmacol. (2015) 760:49-63. doi: 10.1016/j.ejphar.2015.03.083

66. Liu X, Ji Q, Zhang C, Liu X, Liu Y, Liu N, et al. miR-30a acts as a tumor suppressor by double-targeting COX-2 and BCL9 in H. pylori gastric cancer models. Sci Rep. (2017) 7:7113. doi: 10.1038/s41598-017-0 7193-w

67. Baños-Lara MDR, Zabaleta J, Garai J, Baddoo M, Guerrero-Plata A. Comparative analysis of miRNA profile in human dendritic cells infected with respiratory syncytial virus and human metapneumovirus. BMC Res Notes. (2018) 11:432-7. doi: 10.1186/s13104-018-3541-0

68. Agra Andrieu N, Motiño O, Mayoral R, Llorente Izquierdo C, Fernández-Alvarez A, Boscá L, et al. Cyclooxygenase-2 Is a target of microRNA-16 in human hepatoma cells. PLoS ONE. (2012) 7:e50935. doi: 10.1371/journal.pone.0050935

69. Ji Y, He Y, Liu L, Zhong X. MiRNA-26b regulates the expression of cyclooxygenase-2 in desferrioxamine-treated CNE cells. Febs Lett. (2010) 584:961-7. doi: 10.1016/j.febslet.2010.01.036

70. Kim SY, Romero R, Tarca AL, Bhatti G, Lee J, Chaiworapongsa T, et al. miR143 regulation of prostaglandin-endoperoxidase synthase 2 in the amnion: implications for human parturition at term. PLoS ONE. (2011) 6:e24131. doi: 10.1371/journal.pone.0024131

71. Lu L, Byrnes K, Han C, Wang Y, Wu T. miR-21 Targets 15-PGDH and promotes cholangiocarcinoma growth. Mol Cancer Res. (2014) 12:890-900. doi: 10.1158/1541-7786.MCR-13-0419

72. Chahar HS, Corsello T, Kudlicki AS, Komaravelli N, Casola A. Respiratory syncytial virus infection changes cargo composition of exosome released from airway epithelial cells. Sci Rep. (2018) 8:387. doi: 10.1038/s41598-017-18672-5

73. Simpson LJ, Patel S, Bhakta NR, Choy DF, Brightbill HD, Ren X, et al. A microRNA upregulated in asthma airway $\mathrm{T}$ cells promotes TH2 cytokine production. Nat Immunol. (2014) 15:1162-70. doi: 10.1038/ni.3026

74. Singh PB, Pua HH, Happ HC, Schneider C, von Moltke J, Locksley RM, et al. MicroRNA regulation of type 2 innate lymphoid cell homeostasis and function in allergic inflammation. J Exp Med. (2017) 214:3627-43. doi: 10.1084/jem.20170545

75. Stier MT, Bloodworth MH, Toki S, Newcomb DC, Goleniewska K, Boyd KL, et al. Respiratory syncytial virus infection activates IL-13-producing group 2 innate lymphoid cells through thymic stromal lymphopoietin. J Allergy Clin Immun. (2016) 138:814-24.e11. doi: 10.1016/j.jaci.2016.01.050

76. Salimi M, Stoger L, Liu W, Go S, Pavord I, Klenerman P, et al. Cysteinyl leukotriene E4 activates human group 2 innate lymphoid cells and enhances the effect of prostaglandin D2 and epithelial cytokines. J Allergy Clin Immunol. (2017) 140:1090-100.e11. doi: 10.1016/j.jaci.2016.12.958

77. Espinosa K, Bossé Y, Stankova J, Rola-Pleszczynski M. CysLT1 receptor upregulation by TGF- $\beta$ and IL-13 is associated with bronchial smooth muscle cell proliferation in response to LTD4. J Allergy Clin Immun. (2003) 111:1032-40. doi: 10.1067/mai.2003.1451

78. Khan AA, Penny LA, Yuzefpolskiy Y, Sarkar S, Kalia V. MicroRNA17 92 regulates effector and memory CD8 T-cell fates by modulating proliferation in response to infections. Blood. (2013) 121:4473-83. doi: 10.1182/blood-2012-06-435412

79. Araki K, Turner AP, Shaffer VO, Gangappa S, Keller SA, Bachmann MF, et al. mTOR regulates memory CD8 T-cell differentiation. Nature. (2009) 460:108-12. doi: 10.1038/nature08155

80. Mossmann D, Park S, Hall MN. mTOR signalling and cellular metabolism are mutual determinants in cancer. Nat Rev Cancer. (2018) 18:744-57. doi: 10.1038/s41568-018-0074-8

81. Li N, Miao Y, Shan Y, Liu B, Li Y, Zhao L, et al. MiR-106b and miR-93 regulate cell progression by suppression of PTEN via PI3K/Akt pathway in breast cancer. Cell Death Dis. (2017) 8:e2796-e2796. doi: 10.1038/cddis.2017.119

82. Kim SW, Ramasamy K, Bouamar H, Lin AP, Jiang D, Aguiar RCT. MicroRNAs miR-125a and miR-125b constitutively activate the NF$B$ pathway by targeting the tumor necrosis factor alpha-induced protein 3 (TNFAIP3, A20). Proc Natl Acad Sci. (2012) 109:7865-70. doi: $10.1073 /$ pnas. 1200081109

83. Tian B, Yang J, Zhao Y, Ivanciuc T, Sun H, Wakamiya M, et al. Central role of the NF-kappaB pathway in the Scgblal-expressing epithelium in mediating respiratory syncytial virus-induced airway inflammation. J Virol. (2018) 92:e00441-18. doi: 10.1128/JVI.00441-18

84. Taganov KD, Boldin MP, Chang K, Baltimore D. NF-kappaB-dependent induction of microRNA miR-146, an inhibitor targeted to signaling proteins of innate immune responses. Proc Natl Acad Sci. (2006) 103:12481. doi: 10.1073/pnas.0605298103

85. Comer BS, Camoretti-Mercado B, Kogut PC, Halayko AJ, Solway J, Gerthoffer WT. MicroRNA-146a and microRNA-146b expression and antiinflammatory function in human airway smooth muscle. Am J Physiol Lung Cell Mol Physiol. (2014) 307:L727-34. doi: 10.1152/ajplung.00174.2014

86. Cheng HS, Sivachandran N, Lau A, Boudreau E, Zhao JL, Baltimore D, et al. MicroRNA-146 represses endothelial activation by inhibiting pro-inflammatory pathways. Embo Mol Med. (2013) 5:1017-34. doi: 10.1002/emmm.201202318

87. Perry MM, Moschos SA, Williams AE, Shepherd NJ, Larner-Svensson HM, Lindsay MA. Rapid changes in microRNA-146a expression negatively regulate the IL-1beta-induced inflammatory response in human lung alveolar epithelial cells. J Immunol. (2008) 180:5689. doi: 10.4049/jimmunol.180.8.5689

88. Huang C, Liu X, QunZhou, Xie J, Ma T, Meng X, et al. MiR146a modulates macrophage polarization by inhibiting Notch1 pathway in RAW264.7 macrophages. Int Immunopharmacol. (2016) 32:46-54. doi: 10.1016/j.intimp.2016.01.009

89. Takahashi Y, Satoh M, Minami Y, Tabuchi T, Itoh T, Nakamura M. Expression of miR-146a/b is associated with the Toll-like receptor 4 signal in coronary artery disease: effect of renin-angiotensin system blockade and statins on 
miRNA-146a/b and Toll-like receptor 4 levels. Clin Sci. (2010) 119:395-405. doi: 10.1042/CS20100003

90. Marchant D, Singhera GK, Utokaparch S, Hackett TL, Boyd JH, Luo Z, et al. Toll-like receptor 4-mediated activation of p38 mitogen-activated protein kinase is a determinant of respiratory virus entry and tropism. J Virol. (2010) 84:11359-73. doi: 10.1128/JVI.00804-10

91. Ayyar KK, Reddy KVR. MAPK and NF- $\mathrm{KB}$ signalling pathways regulate the expression of miRNA, let-7f in human endocervical epithelial cells. J Cell Biochem. (2018) 119:4751-9. doi: 10.1002/jcb. 26665

92. Whelan JT, Hollis SE, Cha DS, Asch AS, Lee M. Post-transcriptional regulation of the Ras-ERK/MAPK signaling pathway. J Cell Physiol. (2012) 227:1235-41. doi: 10.1002/jcp.22899

93. Jamaluddin M, Casola A, Garofalo RP, Han Y, Elliott T, Ogra PL, et al. The major component of IkappaBalpha proteolysis occurs independently of the proteasome pathway in respiratory syncytial virus-infected pulmonary epithelial cells. J Virol. (1998) 72:4849.

94. Rayavara K, Kurosky A, Stafford SJ, Garg NJ, Brasier AR, Garofalo RP, et al. Proinflammatory effects of respiratory syncytial virus-induced epithelial HMGB1 on human innate immune cell activation. J Immunol. (2018) 201:2753-66. doi: 10.4049/jimmunol.1800558

95. Sheedy FJ. Turning 21: induction of miR-21 as a key switch in the inflammatory response. Front Immunol. (2015) 6:19. doi: 10.3389/fimmu.2015.00019

96. Canfrán Duque A, Rotllan N, Zhang X, Fernández Fuertes M, Ramírez Hidalgo C, Araldi E, et al. Macrophage deficiency of miR-21 promotes apoptosis, plaque necrosis, and vascular inflammation during atherogenesis. Embo Mol Med. (2017) 9:1244-62. doi: 10.15252/emmm.201607492

97. Recchiuti A, Krishnamoorthy S, Fredman G, Chiang N, Serhan CN. MicroRNAs in resolution of acute inflammation: identification of novel resolvin Dl-miRNA circuits. FASEB J. (2010) 25:544-60. doi: 10.1096/fj.10-169599

98. S Boyapalle, Wong T, Garay J, Teng M, San JH, Mohapatra S, et al. Respiratory syncytial virus NS1 protein colocalizes with mitochondrial antiviral signaling protein MAVS following infection. PLoS ONE. (2012) 7:e29386. doi: 10.1371/journal.pone.0029386

99. Kim RY, Horvat JC, Pinkerton JW, Starkey MR, Essilfie AT, Mayall JR, et al. MicroRNA-21 drives severe, steroid-insensitive experimental asthma by amplifying phosphoinositide 3-kinase-mediated suppression of histone deacetylase 2. J Allergy Clin Immun. (2017) 139:519-32. doi: 10.1016/j.jaci.2016.04.038

100. Liu S, Gao L, Wang X, Xing Y. Respiratory syncytial virus infection inhibits TLR4 signaling via up-regulation of miR-26b. Cell Biol Int. (2015) 39:137683. doi: 10.1002/cbin. 10518

101. Mohamed JS, Lopez MA, Boriek AM. Mechanical stretch up-regulates microRNA-26a and induces human airway smooth muscle hypertrophy by suppressing glycogen synthase kinase-3ß. J Biol Chem. (2010) 285:29336-47. doi: 10.1074/jbc.M110.101147

102. Panganiban RP, Wang Y, Howrylak J, Chinchilli VM, Craig TJ, August A, et al. Circulating microRNAs as biomarkers in patients with allergic rhinitis and asthma. J Allergy Clin Immun. (2016) 137: 1423-32. doi: 10.1016/j.jaci.2016.01.029

103. Tam VC, Quehenberger O, Oshansky CM, Suen R, Armando AM, Treuting PM, et al. Lipidomic profiling of influenza infection identifies mediators that induce and resolve inflammation. Cell. (2013) 154:213-27. doi: 10.1016/j.cell.2013.05.052

104. Fang J, Hao Q, Liu L, Li Y, Wu J, Huo X, et al. Epigenetic changes mediated by microRNA miR29 activate cyclooxygenase 2 and lambda-1 interferon production during viral infection. J Virol. (2012) 86:1010-20. doi: 10.1128/JVI.06169-11

105. Seymour ML, Gilby N, Bardin PG, Fraenkel DJ, Sanderson G, Penrose JF, et al. Rhinovirus infection increases 5-lipoxygenase and cyclooxygenase-2 in bronchial biopsy specimens from nonatopic subjects. J Infect Dis. (2002) 185:540-4. doi: 10.1086/338570

106. Gutierrez MJ, Gomez JL, Perez GF, Pancham K, Val S, Pillai DK, et al. Airway secretory microRNAome changes during rhinovirus infection in early childhood. PLOS ONE. (2016) 11:e0162244. doi: 10.1371/journal.pone.0162244
107. Zhengli L, Runan Z, Ling C, Jianxin W, Chunmei Z. Clinical characteristics and leukotriene levels in serum and urine of bronchiolitis children infected with different viruses. Chinese J Exp Clin Virol. (2019) 33:458-62. doi: 10.3760/cma.j.issn.1003-9279.2019.05.003

108. Deng J, Ptashkin RN, Wang Q, Liu G, Zhang G, Lee I, et al. Human metapneumovirus infection induces significant changes in small noncoding RNA expression in airway epithelial cells. Mol Ther Nucleic Acids. (2014) 3:e163. doi: $10.1038 / \mathrm{mtna} .2014 .18$

109. Dimitrov T, Krajcsi P, Hermiston TW, Tollefson AE, Hannink M, Wold WS. Adenovirus E3-10.4K/14.5K protein complex inhibits tumor necrosis factorinduced translocation of cytosolic phospholipase A2 to membranes. J Virol. (1997) 71:2830-7. doi: 10.1128/JVI.71.4.2830-2837.1997

110. Zhao H, Chen M, Tellgren-Roth C, Pettersson U. Fluctuating expression of microRNAs in adenovirus infected cells. Virology. (2015) 478:99-111. doi: 10.1016/j.virol.2015.01.033

111. Haque MM, Murale DP, Lee J. Role of microRNA and oxidative stress in influenza A virus pathogenesis. Int J Mol Sci. (2020) 21:8962. doi: $10.3390 /$ ijms 21238962

112. Gentile DA, Fireman P, Skoner DP. Elevations of local leukotriene C4 levels during viral upper respiratory tract infections. Ann Allergy Asthma Immunol. (2003) 91:270-4. doi: 10.1016/S1081-1206(10)63529-6

113. Taniguchi A, Kawada JI, Go K, Fujishiro N, Hosokawa Y, Maki Y, et al. Comparison of clinical characteristics of human metapneumovirus and respiratory syncytial virus infections in hospitalized young children. Jpn J Infect Dis. (2019) 72:237-42. doi: 10.7883/yoken.JJID.2018.480

114. Jame AJ, Lackie PM, Cazaly AM, Sayers I, Penrose JF, Holgate ST, et al. Human bronchial epithelial cells express an active and inducible biosynthetic pathway for leukotrienes B4 and C4. Clin Exp Allergy. (2007) 37:880-92. doi: 10.1111/j.1365-2222.2007.02733.x

115. Fredman G, Li Y, Dalli J, Chiang N, Serhan CN. Self-limited versus delayed resolution of acute inflammation: temporal regulation of pro-resolving mediators and microRNA. Sci Rep. (2012) 2:639. doi: 10.1038/srep00639

116. Wang D, Li Y, Zhang C, Li X, Yu J. MiR-216a-3p inhibits colorectal cancer cell proliferation through direct targeting COX-2 and ALOX5. J Cell Biochem. (2018) 119:1755-66. doi: 10.1002/jcb.26336

117. Su K, Wang Q, Qi L, Hua D, Tao J, Mangan CJ, et al. MicroRNA674-5p/5-LO axis involved in autoimmune reaction of Concanavalin A-induced acute mouse liver injury. Toxicol Lett. (2016) 258:101-7. doi: 10.1016/j.toxlet.2016.06.010

118. Chen Z, Yang J, Zhong J, Luo Y, Du W, Hu C, et al. MicroRNA-193b$3 p$ alleviates focal cerebral ischemia and reperfusion-induced injury in rats by inhibiting 5-lipoxygenase expression. Exp Neurol. (2020) 327:113223. doi: 10.1016/j.expneurol.2020.113223

119. Jiang X, Hawkins JS, Lee J, Lizama CO, Bos FL, Zape JP, et al. Let7 microRNA-dependent control of leukotriene signaling regulates the transition of hematopoietic niche in mice. Nat Commun. (2017) 8:128. doi: 10.1038/s41467-017-00137-y

120. Bhagat TD, Zhou L, Sokol L, Kessel R, Caceres G, Gundabolu K, et al. miR-21 mediates hematopoietic suppression in MDS by activating TGF- $\beta$ signaling. Blood. (2013) 121:2875-81. doi: 10.1182/blood-2011-12-397067

121. Brungs M, Rådmark O, Samuelsson B, Steinhilber D. Sequential induction of 5-lipoxygenase gene expression and activity in Mono Mac 6 cells by transforming growth factor beta and 1,25-dihydroxyvitamin D3. Proc Natl Acad Sci USA. (1995) 92:107-11.

122. Rådmark $\mathrm{O}$, Werz $\mathrm{O}$, Steinhilber $\mathrm{D}$, Samuelsson B. 5-Lipoxygenase: regulation of expression and enzyme activity. Trends Biochem Sci. (2007) 32:332-41. doi: 10.1016/j.tibs.2007.06.002

123. Hashimoto K, Graham BS, Ho SB, Adler KB, Collins RD, Olson SJ, et al. Respiratory syncytial virus in allergic lung inflammation increases Muc5ac and Gob-5. Am J Resp Crit Care. (2004) 170:306-12. doi: $10.1164 / \mathrm{rccm} .200301-030 \mathrm{OC}$

124. Werz O, Klemm J, Samuelsson B, Radmark O. 5-lipoxygenase is phosphorylated by p38 kinase-dependent MAPKAP kinases. Proc Natl Acad Sci USA. (2000) 97:5261-6. doi: 10.1073/pnas.050588997

125. He F, Xiao Z, Yao H, Li S, Feng M, Wang W, et al. The protective role of microRNA-21 against coxsackievirus B3 infection through targeting the MAP2K3/P38 MAPK signaling pathway. J Transl Med. (2019) 17:335. doi: 10.1186/s12967-019-2077-y 
126. Tan X, Gao Y, Nan Y, Zhang J, Di C, Wang X, et al. Cellular microRNA Let-7a suppresses KSHV replication through targeting MAP4K4 signaling pathways. PLoS ONE. (2015) 10:e0132148. doi: 10.1371/journal.pone.0132148

127. Gonsalves CS, Kalra VK. Hypoxia-mediated expression of 5lipoxygenase-activating protein involves HIF-lalpha and NF-kappaB and microRNAs 135a and 199a-5p. J Immunol. (2010) 184:3878-88. doi: 10.4049/jimmunol.0902594

128. Buckley CD, Gilroy DW, Serhan CN. Proresolving lipid mediators and mechanisms in the resolution of acute inflammation. Immunity. (2014) 40:315-27. doi: 10.1016/j.immuni.2014. 02.009

129. Wei J, Gronert K. Eicosanoid and specialized proresolving mediator regulation of lymphoid cells. Trends Biochem Sci. (2019) 44:214-25. doi: 10.1016/j.tibs.2018.10.007

130. Basil MC, Levy BD. Specialized pro-resolving mediators: endogenous regulators of infection and inflammation. Nat Rev Immunol. (2016) 16:5167. doi: 10.1038/nri.2015.4

131. Liu X, Hou L, Huang W, Gao Y, Lv X, Tang J. The mechanism of long noncoding RNA MEG3 for neurons apoptosis caused by hypoxia: mediated by miR-181b-12/15-LOX signaling pathway. Front Cell Neurosci. (2016) 10:201. doi: 10.3389/fncel.2016.00201

132. Cai Y, Liu J, Cai S, Miao E, Jia C, Fan Y, et al. Eicosapentaenoic acid's metabolism of 15-LOX-1 promotes the expression of miR-101 thus inhibits
Cox2 pathway in colon cancer. Oncotargets Ther. (2020) 13:5605-16. doi: 10.2147/OTT.S237562

133. Werder RB, Lynch JP, Simpson JC, Zhang V, Hodge NH, Poh M, et al. PGD2/DP2 receptor activation promotes severe viral bronchiolitis by suppressing IFN-lambda production. Sci Transl Med. (2018) 10:eaao0052. doi: 10.1126/scitranslmed.aao0052

134. Jackson LM. Cyclooxygenase (COX) 1 and 2 in normal, inflamed, and ulcerated human gastric mucosa. Gut. (2000) 47:762-70. doi: 10.1136/gut.47.6.762

135. Jing Q, Huang S, Guth S, Zarubin T, Motoyama A, Chen J, et al. Involvement of microRNA in AU-rich element-mediated mRNA instability. Cell. (2005) 120:623-34. doi: 10.1016/j.cell.2004.12.038

Conflict of Interest: The authors declare that the research was conducted in the absence of any commercial or financial relationships that could be construed as a potential conflict of interest.

Copyright (c) $2021 \mathrm{Liu}, \mathrm{Fan}, \mathrm{Chen}, \mathrm{Xu}$ and Zhao. This is an open-access article distributed under the terms of the Creative Commons Attribution License (CC BY). The use, distribution or reproduction in other forums is permitted, provided the original author(s) and the copyright owner(s) are credited and that the original publication in this journal is cited, in accordance with accepted academic practice. No use, distribution or reproduction is permitted which does not comply with these terms. 